\title{
ESTIMATING A PREDICTION MODEL FOR THE EARLY IDENTIFICATION OF LOW EMPLOYABILITY GRADUATES IN MALAYSIA
}

\author{
ROSNA AWANG-HASHIM \\ School of Education and Modern Languages \\ Universiti Utara Malaysia \\ 06010 Sintok, Kedah, Malaysia \\ LIM HOCK EAM \\ School of Economics, Finance and Banking \\ Universiti Utara Malaysia \\ 06010 Sintok, Kedah, Malaysia \\ lheam@uum.edu.my \\ BIDIN YATIM \\ School of Quantitative Sciences \\ Universiti Utara Malaysia \\ 06010 Sintok, Kedah, Malaysia \\ TENGKU FAEKAH TENGKU ARIFFIN \\ School of Education and Modern Languages \\ Universiti Utara Malaysia \\ 06010 Sintok, Kedah, Malaysia \\ AINOL MADZIAH ZUBAIRI \\ Kulliyyah of Education \\ International Islamic University Malaysia \\ Jalan Gombak 53100 Kuala Lumpur, Malaysia \\ HANIZA YON \\ Psychometrics Cluster \\ MIMOS Berhad, Technology Park Malaysia \\ 57000 Kuala Lumpur, Malaysia \\ OMAR OSMAN \\ School of Housing, Building and Planning \\ Universiti Sains Malaysia, 11800 Penang, Malaysia
}

Published 17 June 2015

\footnotetext{
*Corresponding author.
} 
This paper describes the development of a prediction model for the early identification of low employability graduates in Malaysia. A total of five proportional hazard models are estimated and using the criteria of percentage correctly and wrongly predicted, a prediction model is selected based on the percentage correctly predicted. The percentile of the predicted hazard rate is used as the employability index (EI). In the context of Malaysia, it is recommended that the 5th percentile graduates be considered as low employability graduates. With this early identification tool, specific intervention programs can be tailored for the right target groups.

Keywords: Early identification; low employability graduate; proportional hazard model; out-ofsample prediction.

JEL Classifications: I23, J64.

\section{Introduction}

Human capital development is an important element in a country's economic growth. It provides knowledgeable and highly competitive workers which in turn, become the catalysts of economic growth. Thus, it comes as no surprise that the Malaysian government has invested heavily in its higher education sector. It is reported that $2.7 \%$ of the country's GDP is spent on higher education, a percentage which is higher than that in Thailand (1.0\%), India (0.7\%), Philippines (0.7\%) and other Asian countries (World Bank, 2007). This figure is also relatively higher than those reported in western countries, such as in Australia (1.1\%), USA (1.5\%), and Japan (0.6\%) (Docampo, 2007). As evidenced by the higher budg et al. location, compared to other countries in the world, the higher education sector in Malaysia is clearly a top priority sector for the government.

In 1996, the Malaysian government liberalized its higher education sector making it possible for the private sector to establish universities. Since this liberalization of the Malaysia higher education (HE) sector, the enrolment of students in HE has increased substantially. According to the Statistics of Higher Education in Malaysia, Ministry of Higher Education (MoHE), there was a total HE enrolment of 1,050,726 in 2010, as against 664,402 in 2002. Consequently, the significant increase in the supply of graduates with the concomitant drastic decrease in the demand for graduates (due to the financial crisis of 1997), has led to the acute problem of graduate unemployment; a grave domestic situation which has persisted until today. Lim (2008), in their study on the graduate labor market outcome in Malaysia, concluded that there was no longer a shortage of graduates in Malaysia. As a matter of fact, the graduate unemployment problem has persisted since the late 1990s.

Graduate unemployment imposes costs on society. Economically, graduate unemployment represents a loss of productivity and also a poor return from higher education investment, either to the individual or the government. Psychologically, it leads to a decrease in happiness (Clark and Oswald, 1994; Winkelmann and Winkelmann, 1998).

With a HE age population enrolment rate of around 35\% (as of 2010), the university education sector in Malaysia is moving toward the massification of higher education. Hence, it is expected that the graduate unemployment problem will persist, and this warrants urgent research on how to build a prediction model which will enable the early detection and identification of low employability graduates. 
The proposal to come up with such a prediction model, as is found in various studies in the literature (for example, see O'Connell et al., 2010; Payne and Payne, 2000), is in this study also viewed as an important approach in addressing the problem of graduate unemployment in Malaysia. Due to its limited resources, it is almost impossible for the Malaysian government to provide intervention programs (such as Finishing School programs to enhance the employability of graduates) for all graduates. If such programs are offered to those who are long-term unemployed, there may be adverse effects on the participants. Inevitable consequences, such as the erosion of skills might occur, and these would make the intervention programs either ineffective, or less effective. In this context, the capacity for early identification of graduates who are at high risk of being unemployed (i.e., have low employability) will enable timely intervention programmes to be rendered before these graduates suffer long-term unemployment. In other words, the early detection and identification allows for the implementation of early, timely and individually tailored intervention programs, and with this tool we can help reduce the problem of graduate unemployment. Intervention programs, as part of the instruments of an active labor market policy, should be designed and delivered to individuals who need it the most (Nativel, 2004).

This paper is aimed at illustrating how the early detection and identification of low employability graduates can be implemented through the estimation of a prediction model for employability index (EI). In particular, this paper seeks to answer the following questions: How do we estimate an index which can be used as an indicator of a graduate's employability? How can the index be used for the early detection and identification of low employability graduate?

The literature review on this issue showed that various studies had been conducted to identify graduate employability and its associated determinants, either in Malaysia or other countries. Typically, probability models were used to estimate the determinants and their effects on the employment status of graduates; whereas, for investigating the unemployment duration of graduates, duration models or survival analysis (such as proportional hazard models) were used (Allison, 1984). It is worth noting the point made by Dockery (2003) and Lim (2010), who advised against using the binary category of employment status (unemployed versus employed) due to the possible effect of aggregate bias. Lim (2010), further suggested that the employment status be disaggregated into the following categories: full-time employment that does commensurate with qualification, full-time employment that does not commensurate with qualification, self-employed, part-time employment, further studies, following courses, unemployed and economically inactive.

Previous studies showed that socio-demographic variables such as age, gender, marital status and working experience were significant determinants of one's employment status (Smith et al., 2000; Lazaro et al., 2000; Morshidi et al., 2004a, 2004b). In addition, the academic achievement of graduates and the types of degrees they obtained were also significant determinants of their employability. For example, Smith et al. (2000) found that graduates with degrees in medicine, education, law and engineering tended to obtain fulltime employment that commensurated with their qualification, and Pietro and Cutillo 
(2006) showed that graduates with poor academic achievements were more likely to be unemployed.

In Malaysia, factors such as ethnicity, English language proficiency, communication skills, and types of degree obtained, were found to influence the probability of employment of a graduate (Morshidi et al., 2004a, 2004b; Wong and Hamali, 2006; Cargile, 2000; Cobb-Clark and Connolly, 2001; Shields and Price, 2001; Lan, 2003). Soft skills were important determinants as well. A study by Morshidi et al. (2008) pointed out that, among the non-job specific skills which were important to the graduate in the job market, were competencies in English language communication, leadership and management, team work and interaction skills. The reasons that graduates were not successful in their job search were mostly due to their lacking in these soft skills.

Studies were also conducted to identify the key employability skills from the employers' perspective. For instance, the study by Sarudin et al. (2011) revealed that some of the critical employability skills highly sought after by employers were: Communication skills (oral and written), interpersonal skills, leadership skills and teamwork skills, and problem solving and decision making skills. In addition, English language proficiency was found to be a critical skill and the most lacking in graduates. Recently, it was also reported that graduates' lack of skills, in particular communication skills, was one of the reasons that they failed in their job interviews in Malaysia (Chew, 2013). In short, the determinants of graduate unemployment had been clearly identified in the literature.

There were also studies on the early identification of low employability graduates. In developed countries, statistical profiling of low employability graduate had already been implemented. For instance, in United Kingdom, Payne and Payne (2000) developed a statistical forecasting model for the early identification of the long-term unemployed using a logistic regression model. They concluded that due to the small sample size and the omission of two important explanatory variables in long term unemployment, the proposed forecasting model suffered from the problem of large errors of prediction.

In the U. S., Black et al. (2003) studied the effectiveness of the Kentucky WPRS (Worker Profiling and Reemployment Services) in predicting the probability of an unemployed person exhausting his/her unemployment benefits (within 12 months). In other words, this was an attempt to forecast those who would be long-term unemployed, i.e., those with low employability. It was found that the use of such a prediction model had significantly lowered the number of unemployment claims (i.e., as a result of the reduction in the number of the long term unemployed).

On the other hand, Lechner and Smith (2007) studied the effectiveness of the statistical prediction of long term unemployed individuals in terms of a post-program employment rate. Similar to Black et al. (2003), they found that the statistical prediction model was better able to reduce the post-program employment rate compared with that made by the prediction based on the case workers' judgement. More recently, O'Connell et al. (2010) constructed a statistical prediction model of the long term unemployed in Ireland using combined administrative and survey data. They suggested that the use of a statistical prediction model to detect and identify the long term unemployed could lead to equity and 
efficiency gains for the authorities (Ireland's Public Employment Services), while at the same time help to reduce the number of long term unemployed cases.

In Malaysia, there were also a few attempts to use the statistical prediction model in the early identification of low employability individuals. Saodah et al. (2006) used discriminant analysis to predict low employability graduates. However, the study concluded that low employability graduates could not be predicted accurately. This difficulty in making the prediction might largely be due to the small sample size and the number of explanatory variables (four) in the prediction models. Lim (2008) estimated a statistical prediction model with a larger number of explanatory variables. The findings of Lim (2008) would seem to suggest that the statistical prediction model was useful in allocating the intervention programs for graduates. He further made the claim that the model proposed had been found feasible for use in the local and Asian contexts.

In summary, it is clear from the literature that a statistical prediction model which is built upon the significant predictors of individual employability is useful in mitigating the problem of long term unemployment. There are three categories of predictors: sociodemographic variables, academic related variables, and soft skills (or employability skills). In addition, the quantity (large sample) and quality (availability of important predictors) of data are important determinants of the effectiveness of any statistical prediction model.

In Malaysia, there are two important sets of data on graduate employability: the Tracer Study (TS) and My3s (Malaysian Soft Skills Scale). The TS provides information about the employment status of graduates and their socio-demographic information, whereas My3s measures the level of the soft skills of graduates. These two data sets, if combined, will provide the input needed by the estimation models to carry out the early detection and identification of low employability graduates. This paper aims to illustrate how such a model can be estimated and used for this very purpose.

The paper consists of four sections. Section 1 provides an introductory sketch of the graduate employment scene in Malaysia. It also includes a brief literature review on graduate unemployment and the early detection and identification of low employability graduates. Section 2 describes the data and methodology of this paper. Results and interpretations are presented in the Section 3. Finally, Section 4 concludes with the findings.

\section{Data and Methodology}

\subsection{Data}

This paper used a dataset which drew data from a TS and My3s. The respondents in the My3s 2009 (data which were collected while the respondents were still in their final year of university studies) were matched with a 2010 TS (data which were collected when the respondents had graduated and entered the labor market) using their respective national identification numbers. The TS and My3s were conducted by the Ministry of Education Malaysia (formerly known as the MOHE, Malaysia) and thus, these two data sets were the best available data on fresh graduates in Malaysia, either quantitatively (sample size) or qualitatively (richness of information). The TS was conducted using an online survey for fresh graduates who were scheduled to attend their upcoming convocation. The time lapse 
between the convocation (i.e., the date when the graduates took part in the TS) and date of the start of their job search (i.e., the date when the graduates completed their studies) was typically between three and six months. For some of the graduates, and the number is small, they might attend their convocation one year after they had completed their studies. Thus, the TS was intended for fresh graduates only.

There were a total of 8757 respondents in My3s 2009 and a total of 224,776 respondents in TS 2010. However, only a total of 3103 respondents $(35.43 \%)$ were successfully matched with the TS and useable for the analysis in this paper. This low percent is due to three factors: missing values in the national identification numbers (3889 or 44.41\%); missing values in some important variables, such as the date of study completion and commencement of work $(1033 ; 11.8 \%)$; and excluding graduates who graduated with degree programs which guaranteed job placements, such as teaching and medical degrees (732; 8.36\%). Nevertheless, this low percent did not have a significant impact on our data set as the present paper focused mainly on illustrating how a statistical prediction model could be developed using the existing data, and hence, the findings could be replicated using a better data set of the TS and My3s once they were made available. Moreover, even with only around a $36 \%$ matching record, the sample has a wide coverage. It covers 363 types of degree programs, 15 public universities and 19 private universities. Thus, this is the best available matching data provided by the MOHE, i.e., the highest authority in the higher education sector.

Thus, although it was only a partial total of the overall number of respondents in My3s 2009 and TS 2010, it was the best available data for our use to illustrate how the early detection and identification of low employability graduates could be implemented.

It is important to note that the identities of the graduates involved in the study and used in the analyses in this paper will remain strictly anonymous. The results will not lead to the identification of any individual in the data. For this purpose, some variables were labeled as anonymous.

\subsection{Methodology}

The building of the prediction model for the early identification of low employability graduates involved four important steps.

\subsubsection{First step: Merge the two sets of data}

The TS and My3s data were combined and $15 \%$ of this total sample was randomly selected as the validation sample; the remaining $85 \%$ was used as the estimation sample. Following a rule of thumb, the percentage of randomly selected validation sample should have a sufficient sample size (a few hundred observations) for the purpose of the out-of-sample forecast.

\subsubsection{Second step: Estimate and select the prediction model}

Five major Proportional Hazard models are estimated and they are: Cox, Exponential, Piecewise-constant, Weibull and Gompertz. In general, the Proportional Hazard model is as 
specified below:

$$
h_{i}(t)=h_{0}(t) \exp \left[\beta^{\prime} X\right] \quad i=1,2, \ldots, n,
$$

where $X$ is matrix of independent variables, $\beta$ co-efficients vector, $h_{0}(t)$ baseline hazard and $h_{i}(t)$ hazard rate.

The hazard rate, $h(t)$, represents the instantaneous probability of exit from an unemployment state, that is, gaining employment that does commensurate with one's qualification, at time $t$, conditional on being unemployed until time $t$. Mathematically, the hazard rate could be represented by the following:

$$
h(t)=\lim _{\Delta t \rightarrow 0} \frac{\operatorname{Pr}(t \leq T<t+\Delta t) \mid T \geq t)}{\Delta t},
$$

where $T$ is the survival time.

The selection of independent variables (or predictors) in the proportional hazard model is crucial to the performance of the prediction model. It is suggested that the findings of previous studies should be the basis for the selection of predictors. The literature review (as presented in Section 1) suggests the following three categories of predictors: First, socio-demographic related variables (such as age, gender and parental income); second, academic related variables (such as CGPA, types of degrees, university and English proficiency); and third, soft skills or employability skills (such as communication, leadership and problem solving skills). Thus, in the present study, these three categories of variables are included as predictors in the estimated model. In addition, the variables represent graduates' satisfaction with their higher education learning process (including various aspects such as the curriculum, career, staff, facilities, and language proficiency (see Appendix $\mathrm{C}$ for the list of variables).

Different assumptions on the baseline hazard will lead to different types of Proportional Hazard model. Assuming that the baseline hazard is constant, as in $h\left(t \mid x_{j}\right)=\exp \left(x_{j} \beta\right)$, we obtain the Exponential model. If we assume that the baseline hazard can be a nonlinear increase or reduced by the value of $\mathrm{p}$, as in $h\left(t \mid x_{j}\right)=p t^{p-1} \exp \left(\beta_{0}+x_{j} \beta\right)$, we obtain the Weibull model.

On the other hand, if we assume the nonlinear increase or reduction of baseline hazard is affected by gamma, as in $h\left(t \mid x_{j}\right)=\exp (\gamma t) \exp \left(\beta_{0}+x_{j} \beta\right)$, we obtain the Gompertz model. If we assume that the baseline hazard varies in step function of a set of time dummy variables, as in $h\left(t \mid x_{j}\right)=\exp \left(\beta_{0}+D_{j} \alpha+x_{j} \beta\right)$ we obtain the Piecewise constant model. Finally, if we do not impose any parametric assumption on the baseline hazard, we obtain the Cox model. Thus, the Cox model is a semi-parametric model.

Since the main objective of the model was for early detection and identification, i.e., forecasting, the percentage correctly predicted on the validation sample was the selection criteria (estimated model with the highest percentage of correctly predicted would be selected as the prediction model for the early identification of low employability graduates). The percentage correctly predicted refers to the percentage of unemployed respondents from the total number of respondents who have been identified as low employability respondents (using EI, which will be explained shortly in the fourth step). 


\subsubsection{Third step: Estimate the predicted hazard rate for each respondent}

The hazard rate was estimated for each respondent using the selected prediction model (in step 2). This estimated hazard rate represents each respondent's probability of exit from unemployment through full time employment that does commensurate with one's qualification. We could use the significant predictors (as found in step 2) in estimating the predicted hazard rate.

\subsubsection{Fourth step: Construct an EI for each respondent}

Finally, the percentile ranking of the predicted hazard rate was calculated. This ranking represented the EI. The basic concept of percentile ranking of the predicted hazard rate is similar to the "percentile ranking for examinee" in the Graduate Record Examinations (GRE) test (see: http://www.testmasters.net/greabout/scoring-scale). The predicted hazard rate of each respondent is ranked in percentile which could be interpreted as follows:

(a) Bottom 5\%: The value of the predicted hazard is at a level where $95 \%$ of the respondents (all) are above it.

(b) Top 5\%: The value of the predicted hazard is at a level where 5\% of the respondents (all) are above it.

For example, given four respondents as in the following schedule:

\begin{tabular}{ccccc}
\hline$n$ & Predicted Hazard Rate & Percentile Ranking & Bottom 5\% & Top 5\% \\
\hline 1 & 0.41 & 1.00 & 0 & 1 \\
2 & 0.31 & 0.67 & 0 & 0 \\
3 & 0.25 & 0.33 & 0 & 0 \\
4 & 0.12 & 0.00 & 1 & 0 \\
\hline
\end{tabular}

The respondent number 1 is at the top $5 \%$ in the percentile ranking. The respondent number 4 is at the bottom 5\%. Since the percentile ranking reflects the relative position of employability (probability of exit from unemployment) and take values from 0 to 1 , we could use it as the EI of respondents. The bottom 5\% is taken as the cut-off point for low employability based on the $90 \%$ confidence interval which divided the sample into two extreme values, bottom 5\% and top 5\%. Figure 1 depicts these four steps.

\section{RESULTS}

\subsection{Descriptive analysis}

The descriptive analysis focused on the labor market outcomes of graduates. From Table 1, it was found that there was around $27 \%$ of the sample who were employed full-time, with employment that did commensurate with their qualification (in graduate jobs). More than half of the sample was unemployed $(54.27 \%$ ). A total of $39.44 \%$ of the graduates were 
I. First step:

Combine data

II. Second step:

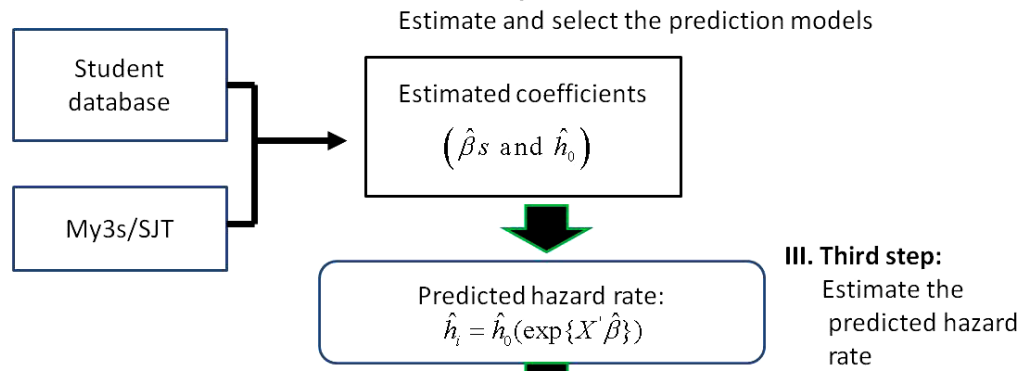

Table 1. Employment Status

\begin{tabular}{lcc}
\hline & Freq. & $\%$ \\
\hline Unemployed & 1,684 & 54.27 \\
Part-time employed & 149 & 4.80 \\
Full-time employment that does not commensurate with qualification & 231 & 7.44 \\
Full-time employment that does commensurate with qualification & 844 & 27.2 \\
Further studies & 58 & 1.87 \\
Others & 137 & 4.42 \\
\hline
\end{tabular}

employed (full time employment that did commensurate with qualification, $27.2 \%$; full time employment that did not commensurate with qualification, $7.44 \%$; and part time employment, $4.8 \%$ ). Comparing these figures to the published report of TS $2009,45.1 \%$ of the graduates were employed, either full time or part time (see TS Report 2009, Chapter 1, p. 3). Thus, there was a difference of $5.66 \%$; however, as the present paper was focused on developing a prediction model which could be replicated with other datasets, there should not be a significant cause of concern over the issue of the representativeness of the sample used.

With regard to the unemployment duration, it can be seen from Table 2, that the unemployed graduates experienced a mean unemployment duration of 114 days (approximately $3 \frac{1}{2}$ months of being unemployed). The full-time employed graduates had the lowest mean unemployment duration of 68 days (employment that did commensurate with qualification). It is important to note that as the TS data is focused on fresh graduates, we 
Table 2. Employment Status and Unemployment Duration

\begin{tabular}{lc}
\hline Employment Status & $\begin{array}{c}\text { Mean Unemployment } \\
\text { Duration (days) }\end{array}$ \\
\hline Unemployed & 114 \\
Part-time employed & 77 \\
Full-time employment that does not commensurate & 68 \\
$\quad$ with qualification & \\
Full-time employment that does commensurate & 80 \\
$\quad$ with qualification & \\
Further studies & 132 \\
Others & 144 \\
\hline
\end{tabular}

would expect that the length of unemployment duration could be capped at the maximum of 180 days.

\subsection{Estimation of a prediction model for employability index}

As illustrated by Figure 1, there were four steps in the estimation of the prediction model.

\subsubsection{Step 1: Combining the data sets}

The data from the TS and My3s were combined by matching the identification numbers of the respondents. For other sets of data which had ready information on the labor market and soft skills, this step could be skipped. Then, we randomly selected $15 \%$ from the total sample. This $15 \%$ sample was the validation sample. The randomness in selection ensured that there was a high representation in the validation sample. Indeed, the validation sample was found to have high similarity with the estimation sample (and total sample as well) in terms of employment status and unemployment duration.

\subsubsection{Step 2: Estimating and selecting the prediction model}

The five Proportional Hazard Models were estimated (see Appendix A). Here we compared the percentage correctly predicted (which meant those who were unemployed and were ranked at the bottom by the estimated hazard rate) with the percentage wrongly predicted (which meant those who were employed full time with employment that did commensurate

Table 3. Percentage Correctly and Wrongly Predicted in Cox Model

\begin{tabular}{lcccccccccc}
\hline & \multicolumn{8}{c}{ Low Employability Graduates: Bottom } \\
\cline { 2 - 11 } Out-of-Sample & $5 \%$ & $10 \%$ & $15 \%$ & $20 \%$ & $25 \%$ & $30 \%$ & $35 \%$ & $40 \%$ & $45 \%$ & $50 \%$ \\
\hline \% Correctly predicted & 80.95 & 73.17 & 70.49 & 69.14 & 64.36 & 64.46 & 62.68 & 62.35 & 62.09 & 60.48 \\
\% Wrongly predicted & 4.76 & 4.88 & 6.56 & 9.88 & 13.86 & 14.05 & 15.49 & 16.05 & 17.03 & 17.33 \\
$n$ & 21 & 41 & 61 & 81 & 101 & 121 & 142 & 162 & 182 & 202 \\
\hline
\end{tabular}


with qualification and were ranked at the top by the estimated hazard rate) provided by the different prediction models. It was found that the Cox Model had the highest percentage of correctly predicted and the lowest percentage of wrongly predicted. For the bottom 5\% of low employability graduates, the percentage correctly and wrongly predicted was $80.95 \%$ and $4.76 \%$ respectively. The second best model, the Piecewise-constant Exponential model, achieved only a $60.43 \%$ correctly predicted result (see Table 3 and Appendix B for details).

Thus, the Cox model was selected as the best prediction model. The estimated model also suggested that the determinants (with a significant and positive effect on one's probability of exit from unemployment through employment that did commensurate with qualification) were: Gender, age, CGPA, types of degree, types of university, soft skills, and satisfaction with the counseling on career and job interviews, and English language proficiency. These significant determinants were indeed similar to those found in the literature.

\subsubsection{Step 3: Estimating the predicted hazard rate}

Based on the estimated coefficients $(\hat{\beta})$ of the Cox model and the values of independent variables $(X s)$, we could predict the hazard rate $\left(\hat{h}_{i}(t)\right)$ for each of the graduates. We could use only the predictors which were found to be significant in predicting the hazard rate. This was to ensure that the insignificant predictors would not influence the early identification of low employability graduates. This predicted hazard rate represented the estimated probability of exit from unemployment through full time employment that did commensurate with qualification. Thus, it could be used as an indicator of a graduate's employability.

\subsubsection{Step 4: Constructing the employability index}

The predicted hazard rate of each graduate was ranked in order of percentile (from value of 0 to 1$)$. This percentile of predicted hazard rate represented the EI of each graduate. For instance, a graduate with the EI (i.e., percentile rank) of 0.1 implied that the employability of this graduate was at the bottom $10 \%$; there were $90 \%$ graduates above him/her. On the other hand, another graduate with an EI of 0.9 implied that this graduate was on the top $10 \%$ of the employability ranking.

This would seem to suggest that the early detection and identification of low employability graduates, using the prediction model (estimated Cox Model), can be applied to the final year students. Many of the values of the independent variables such as gender, age, CGPA, types of degree, and types of university are available. For independent variables in which the values are not available, we can replace these values with the mean values from the historical data. As such, the EI can be constructed and students with the EI of 0.05 and below are identified as the potential low employability graduates (bottom 5\% in terms of percentile of predicted hazard rate).

Having carried out these steps, the individual profile of the graduates can then be analyzed to ascertain the specific kinds of intervention needed to improve the employability of these graduates. It is important to note that some significant variables such as 
gender and age are not changeable and therefore, cannot be intervened. Low employability students who have low proficiency of English (as shown by the value of independent variable which represents the English language proficiency) will be recommended to attend an appropriate English language course. Those who are weak in soft skills (as shown by the value of the independent variable which represents the level of soft skills) will have to attend courses to improve the relevant soft skills.

Thus, the "at risk" low employability graduates will have a chance to enhance their employability before they enter the labor market; otherwise they are likely to experience the possibility of long term unemployment.

\subsection{An example of EI application}

To illustrate how the EI could be constructed and used for intervention recommendations, we simulated an example of five undergraduate students as follows:

It was assumed that these five students were in their final year of studies, i.e., the CGPA represented their current CGPA and they had participated in the My3s study. However, they are yet to take part in the TS. Hence, the values of C3, C7, C12 and C13 were unknown and the historical mean values would replace these missing values (based on the sample, these mean values are 3.81, 4.06, 4.56 and 4.05, respectively).

Based on this information, we constructed the EI for these five students. The prediction model based on the significant level of 5\% (Cox Proportional Model, see Appendix A) was as presented in Eq. (D.1) (see Appendix D). To estimate the predicted hazard rate, we replaced the variables with the values of the students (as in Table 4). The predicted hazard rate for the students was as presented in Table 5. The percentile rank was constructed for the range of the predicted hazard rate (as shown in Table 5).

This percentile rank represented the EI of the student. For instance, student number 5 had an EI of zero. This implied that she was ranked the lowest in terms of employability. Student number 5 was therefore, identified as in the category of low employability graduates. Based on her specific individual needs, whether they were English language courses

Table 4. An Application Example

\begin{tabular}{cccccccccccc}
\hline S & Gender & Degree & Uni & CGPA & Eng & Inc (RM) & em & C3 & C7 & C12 & C13 \\
\hline 1 & F & 7 & 11 & 3.91 & 5 & $3001-5000$ & 7.45 & 3.81 & 4.06 & 4.56 & 4.05 \\
2 & M & 8 & 18 & 3.55 & 4 & $1501-2000$ & 6.80 & 3.81 & 4.06 & 4.56 & 4.05 \\
3 & M & 11 & 18 & 3.24 & 4 & $501-1000$ & 6.23 & 3.81 & 4.06 & 4.56 & 4.05 \\
4 & F & 2 & 13 & 3.14 & 2 & $1001-1500$ & 8.63 & 3.81 & 4.06 & 4.56 & 4.05 \\
5 & F & 2 & 13 & 2.81 & 3 & $1001-1500$ & 8.00 & 3.81 & 4.06 & 4.56 & 4.05 \\
\hline
\end{tabular}

Note: $\mathrm{S}=$ student; F-female, $\mathrm{M}=$ male; Uni. = university; inc = family income; CEng = civil engineering; MEng = Mechanical Engineering; ComSc = Computer Sciences; Islamic = Islamic Studies; Eng = English language ( 1 being low and 5 being high); Inc = monthly family income; Uni = University; em = etiquette and moral; C3, 7, 9, 10, 12 and 13 represent the control variables 3, 7, 9, 10, 12 and 13 respectively (these variables have to be classified as 'anonymous' for reasons of data confidentiality and sensitivity). 
Table 5. EI Construction

\begin{tabular}{lcc}
\hline Student & Predicted Hazard Rate & EI (Percentile Rank) \\
\hline 1 & 0.019623 & 0.50 \\
2 & 0.023597 & 1.00 \\
3 & 0.021586 & 0.75 \\
4 & 0.010281 & 0.25 \\
5 & 0.009539 & 0.00 \\
\hline
\end{tabular}

(which can improve her English language proficiency) and also courses which could improve her CGPA (such as motivation courses), selection could then be made from the array of intervention programs available. This was because she scored low in employability due to her low scores in English language proficiency and CGPA (see Table 4).

On the other hand, student numbers 2 and 3 were predicted to score high in the EI and thus, no intervention courses were necessary for them. In this context, the EI also helped to allocate scarce resources (intervention programs) to only those who really needed them.

\section{Conclusion}

The results of the descriptive analysis reveal that more than half of the graduates surveyed are yet to be employed. In general, it is also clear that determinants with a positive influence on a graduate's employability are gender, age, CGPA, types of degree, types of university, soft skills, and satisfaction on counseling on career and job interviews, and English language proficiency. This paper has illustrated how a prediction model could be built for the early detection and identification of low employability graduates. The high percentage correctly predicted and low percentage of wrongly predicted seem to suggest the feasibility of this early detection and identification model. A simple example of how early detection and identification can be predicted was amply demonstrated in the case study of five students, and thus, confirms the usefulness of this prediction tool.

This capability in the early detection and identification of low employability graduates has policy implications. First, it enables intervention programs to be tailored to the needs of a specific target group - the low employability graduates. Second, it ensures that the intervention programs are not imposed redundantly on graduates who do not need it (high employability graduates). Thus, this early detection and identification tool enhances the efficiency and effectiveness of the intervention programs.

The EI is a relative measure of the predicted hazard rate (probability of exit from unemployment through obtaining full time employment that does commensurate with qualification) for graduates from various universities. The hazard rates are predicted by using the effects of university and other significant variables. Thus, the influence of the university factor has been taken into consideration. The EI construct presented here is from 
the perspective of the ministry (national level); it is to help them identify at an early stage, the low employability graduates found across the different universities in Malaysia. ${ }^{1}$

The My3s variables appear to have a low predictive power on the employability of graduates. It could be dropped in place of the full sample of the TS and thus, avoiding any potential truncation bias due to the low matching between My3s and TS data sets. Results of the matching data set and full TS data set could be compared on the basis of their predictive performance in the early identification of low employability graduates. ${ }^{1}$ However, as the full TS data set is not made available due to data confidentiality, the present study is not able to investigate this contention. We would like to suggest that future studies should replicate the procedure of the present study with a better data set once this is made available.

\section{Acknowledgments}

We would like to thank the Ministry of Education (formerly known as Ministry of Higher Education), Malaysia for generously providing a financial grant for this study. Thanks are also due to the anonymous referees of the Singapore Economic Review (SER) whose insightful comments have improved this paper substantially.

\section{Appendix A. Estimated Models}

Table A.1. Estimated Models

\begin{tabular}{|c|c|c|c|c|c|c|c|c|c|c|}
\hline \multirow[b]{2}{*}{ Variable } & \multicolumn{2}{|c|}{ Cox } & \multicolumn{2}{|c|}{ Exponential } & \multicolumn{2}{|c|}{$\begin{array}{l}\text { Piecewise-Constant } \\
\text { Exponential }\end{array}$} & \multicolumn{2}{|c|}{ Weibull } & \multicolumn{2}{|c|}{ Gompertz } \\
\hline & $\begin{array}{c}\text { Hazard } \\
\text { Ratio }\end{array}$ & $P$-Value & $\begin{array}{c}\text { Hazard } \\
\text { Ratio }\end{array}$ & $P$-Value & $\begin{array}{c}\text { Hazard } \\
\text { Ratio }\end{array}$ & $P$-Value & $\begin{array}{c}\text { Hazard } \\
\text { Ratio }\end{array}$ & $P$-Value & $\begin{array}{c}\text { Hazard } \\
\text { Ratio }\end{array}$ & $P$-Value \\
\hline Dmale & 1.6056 & 0.0000 & 1.6311 & 0.0000 & 1.7494 & 0.0000 & 1.5962 & 0.0000 & 1.6885 & 0.0000 \\
\hline e_umur & 1.0702 & 0.0790 & 1.0753 & 0.0730 & 1.0777 & 0.0930 & 1.0744 & 0.0650 & 1.0762 & $\mathbf{0 . 0 8 5 0}$ \\
\hline Dinc1000 & 1.3281 & 0.1290 & 1.3583 & 0.1210 & 1.4129 & 0.1050 & 1.3481 & 0.1160 & 1.3760 & 0.1210 \\
\hline Dinc1500 & 1.5363 & 0.0210 & 1.5575 & 0.0240 & 1.6951 & 0.0140 & 1.5444 & 0.0210 & 1.5925 & 0.0240 \\
\hline Dinc2000 & 1.2459 & 0.2640 & 1.2105 & 0.3520 & 1.3187 & 0.2120 & 1.2137 & 0.3280 & 1.2292 & 0.3340 \\
\hline Dinc2500 & 1.4034 & 0.0950 & 1.4273 & 0.0920 & 1.5350 & 0.0670 & 1.4048 & 0.0930 & 1.4736 & 0.0810 \\
\hline Dinc 3000 & 1.0664 & 0.7640 & 1.1131 & 0.6250 & 0.9867 & 0.9580 & 1.1283 & 0.5650 & 1.0752 & 0.7560 \\
\hline Dinc5000 & 1.3238 & 0.1510 & 1.2647 & 0.2460 & 1.3779 & 0.1500 & 1.2599 & 0.2340 & 1.2994 & 0.2190 \\
\hline Dinc5001 & 1.3001 & 0.2040 & 1.2907 & 0.2300 & 1.3624 & 0.1910 & 1.3004 & 0.1980 & 1.2943 & 0.2490 \\
\hline e_cgpa & 1.5315 & 0.0010 & 1.5385 & 0.0010 & 1.5302 & 0.0060 & 1.5353 & 0.0010 & 1.5297 & 0.0040 \\
\hline English & 1.1522 & 0.0400 & 1.1520 & 0.0550 & 1.1866 & 0.0310 & 1.1414 & 0.0620 & 1.1681 & 0.0450 \\
\hline Degree1 & 0.5903 & 0.0270 & 0.5605 & 0.0210 & 0.5329 & 0.0210 & 0.5624 & 0.0170 & 0.5579 & 0.0270 \\
\hline Degree2 & 0.1044 & 0.0000 & 0.1474 & $\mathbf{0 . 0 0 0 0}$ & 0.0686 & 0.0000 & 0.1673 & 0.0000 & 0.1077 & $\mathbf{0 . 0 0 0 0}$ \\
\hline
\end{tabular}

\footnotetext{
${ }^{1}$ We would like to thank the anonymous referee who pointed out these issues.
} 
Table A.1. (Continued)

\begin{tabular}{|c|c|c|c|c|c|c|c|c|c|c|}
\hline \multirow[b]{2}{*}{ Variable } & \multicolumn{2}{|c|}{ Cox } & \multicolumn{2}{|c|}{ Exponential } & \multicolumn{2}{|c|}{$\begin{array}{l}\text { Piecewise-Constant } \\
\text { Exponential }\end{array}$} & \multicolumn{2}{|c|}{ Weibull } & \multicolumn{2}{|c|}{ Gompertz } \\
\hline & $\begin{array}{c}\text { Hazard } \\
\text { Ratio }\end{array}$ & $P$-Value & $\begin{array}{c}\text { Hazard } \\
\text { Ratio }\end{array}$ & $P$-Value & $\begin{array}{c}\text { Hazard } \\
\text { Ratio }\end{array}$ & $P$-Value & $\begin{array}{c}\text { Hazard } \\
\text { Ratio }\end{array}$ & $P$-Value & $\begin{array}{c}\text { Hazard } \\
\text { Ratio }\end{array}$ & $P$-Value \\
\hline Degree3 & 0.2453 & 0.0000 & 0.2240 & 0.0000 & 0.2130 & 0.0000 & 0.2305 & 0.0000 & 0.2174 & 0.0000 \\
\hline Degree4 & 0.1080 & 0.0000 & 0.0908 & 0.0000 & 0.1018 & 0.0000 & 0.0899 & 0.0000 & 0.0957 & 0.0000 \\
\hline Degree5 & 0.4488 & 0.0050 & 0.4065 & 0.0030 & 0.3796 & $\mathbf{0 . 0 0 3 0}$ & 0.4109 & 0.0020 & 0.4014 & 0.0040 \\
\hline Degree6 & 0.9929 & 0.9790 & 0.9381 & 0.8200 & 0.8702 & 0.6520 & 0.9318 & 0.7920 & 0.9360 & 0.8230 \\
\hline Degree7 & 1.2324 & 0.4540 & 1.2878 & 0.3950 & 1.1945 & 0.5870 & 1.2382 & 0.4500 & 1.3046 & 0.3990 \\
\hline Degree8 & 0.9948 & 0.9850 & 1.0155 & 0.9570 & 0.8699 & 0.6630 & 1.0069 & 0.9800 & 0.9861 & 0.9630 \\
\hline Degree9 & 0.9618 & 0.8790 & 0.9602 & 0.8800 & 0.9316 & 0.8110 & 0.9349 & 0.7930 & 0.9772 & 0.9350 \\
\hline Degree10 & 0.9055 & 0.7220 & 0.7595 & 0.3520 & 0.8737 & 0.6720 & 0.7401 & 0.2900 & 0.8143 & 0.5080 \\
\hline Degree11 & 0.7862 & 0.4960 & 0.9038 & 0.7730 & 0.6159 & 0.2810 & 0.9086 & 0.7710 & 0.8429 & 0.6570 \\
\hline Degree12 & 0.8766 & 0.6730 & 0.9021 & 0.7470 & 0.8158 & 0.5710 & 0.8845 & 0.6890 & 0.9031 & 0.7640 \\
\hline University 1 & 0.7639 & 0.3770 & 0.7201 & 0.3300 & 0.7351 & 0.3800 & 0.7051 & 0.2850 & 0.7396 & 0.3800 \\
\hline University2 & 0.8745 & 0.5840 & 0.6494 & 0.1350 & 0.6240 & 0.1210 & 0.7623 & 0.3240 & 0.5335 & 0.0370 \\
\hline University3 & 0.7306 & 0.2740 & 0.6101 & 0.1320 & 0.5758 & 0.1090 & 0.7184 & 0.2920 & 0.4859 & 0.0350 \\
\hline University4 & 0.6148 & 0.0200 & 0.4858 & 0.0030 & 0.4567 & 0.0020 & 0.5832 & 0.0200 & 0.3895 & 0.0000 \\
\hline University5 & 0.8114 & 0.4830 & 0.7273 & 0.3500 & 0.7585 & 0.4390 & 0.7229 & 0.3220 & 0.7444 & 0.3980 \\
\hline University6 & 0.5539 & 0.0650 & 0.3950 & 0.0100 & 0.4052 & 0.0160 & 0.4544 & 0.0210 & 0.3342 & 0.0030 \\
\hline University7 & 0.2524 & 0.0240 & 0.2795 & 0.0420 & 0.3363 & $\mathbf{0 . 0 8 8 0}$ & 0.2391 & 0.0210 & 0.3148 & 0.0670 \\
\hline University8 & 0.3219 & 0.0060 & 0.3207 & 0.0070 & 0.3551 & 0.0170 & 0.2952 & 0.0030 & 0.3451 & 0.0120 \\
\hline University9 & 0.5545 & 0.0120 & 0.5918 & 0.0690 & 0.6198 & 0.1160 & 0.5667 & 0.0390 & 0.6096 & 0.0940 \\
\hline University 10 & 1.2516 & 0.6420 & 1.3578 & 0.6290 & 2.6748 & 0.0980 & 1.0488 & 0.9400 & 1.9249 & 0.2820 \\
\hline University 11 & 0.8871 & 0.5710 & 0.6403 & 0.0910 & 0.6769 & 0.1640 & 0.7345 & 0.2140 & 0.5486 & 0.0280 \\
\hline University 12 & 0.1185 & 0.0000 & 0.1353 & 0.0000 & 0.0703 & $\mathbf{0 . 0 0 0 0}$ & 0.1900 & 0.0000 & 0.0793 & 0.0000 \\
\hline University 13 & 0.1356 & 0.0000 & 0.1543 & 0.0000 & 0.0867 & 0.0000 & 0.2073 & 0.0000 & 0.0969 & 0.0000 \\
\hline University 14 & 0.0557 & 0.0000 & 0.1241 & 0.0000 & 0.0274 & 0.0000 & 0.1921 & 0.0000 & 0.0538 & 0.0000 \\
\hline University 15 & 0.4785 & 0.0230 & 0.4757 & 0.0250 & 0.3195 & $\mathbf{0 . 0 0 3 0}$ & 0.6138 & 0.1220 & 0.3230 & 0.0020 \\
\hline University 16 & 0.4663 & 0.0080 & 0.3308 & 0.0010 & 0.3245 & 0.0010 & 0.3926 & 0.0030 & 0.2711 & 0.0000 \\
\hline University 17 & 0.3282 & 0.0000 & 0.3667 & 0.0000 & 0.1531 & $\mathbf{0 . 0 0 0 0}$ & 0.4519 & 0.0040 & 0.2452 & $\mathbf{0 . 0 0 0 0}$ \\
\hline $\operatorname{cs} 10$ & 0.7023 & 0.5610 & 0.8231 & 0.7580 & 0.7827 & 0.7360 & 0.8249 & 0.7510 & 0.8094 & 0.7540 \\
\hline $\operatorname{cs} 102$ & 1.0273 & 0.4960 & 1.0178 & 0.6680 & 1.0213 & 0.6550 & 1.0176 & 0.6590 & 1.0190 & 0.6680 \\
\hline ctps 10 & 0.9812 & 0.9760 & 0.9667 & 0.9590 & 0.8155 & 0.7800 & 0.9734 & 0.9660 & 0.9457 & 0.9360 \\
\hline ctps102 & 1.0023 & 0.9580 & 1.0027 & 0.9530 & 1.0144 & 0.7780 & 1.0025 & 0.9540 & 1.0040 & 0.9340 \\
\hline ts 10 & 1.2172 & 0.7660 & 1.4124 & 0.6220 & 1.3246 & 0.7230 & 1.4194 & 0.5990 & 1.3740 & 0.6710 \\
\hline ts 102 & 0.9849 & 0.7330 & 0.9746 & 0.5870 & 0.9815 & 0.7270 & 0.9738 & 0.5550 & 0.9772 & 0.6490 \\
\hline em10 & 0.4564 & 0.0370 & 0.4016 & 0.0300 & 0.4465 & 0.0840 & 0.3941 & 0.0190 & 0.4293 & 0.0570 \\
\hline em102 & 1.0559 & 0.0380 & 1.0651 & 0.0310 & 1.0572 & 0.0870 & 1.0666 & 0.0200 & 1.0602 & 0.0580 \\
\hline ls 10 & 1.5762 & 0.5060 & 1.5640 & 0.5530 & 2.0189 & 0.4050 & 1.4874 & 0.5810 & 1.6674 & 0.5200 \\
\hline 1s 102 & 0.9803 & 0.6590 & 0.9802 & 0.6860 & 0.9645 & 0.5130 & 0.9831 & 0.7180 & 0.9767 & 0.6510 \\
\hline 1110 & 1.4028 & 0.5510 & 1.2429 & 0.7260 & 1.4223 & 0.6030 & 1.2578 & 0.7000 & 1.3029 & 0.6840 \\
\hline 11102 & 0.9697 & 0.4260 & 0.9780 & 0.5970 & 0.9680 & 0.4790 & 0.9775 & 0.5720 & 0.9743 & 0.5550 \\
\hline kk10 & 1.5486 & 0.0790 & 1.5361 & 0.1020 & 1.6977 & 0.0750 & 1.4977 & 0.1050 & 1.5949 & 0.0950 \\
\hline kk102 & 0.9666 & 0.0820 & 0.9679 & 0.1110 & 0.9593 & 0.0740 & 0.9699 & 0.1160 & 0.9646 & 0.0990 \\
\hline Ku_dkerja & 0.9702 & 0.6320 & 0.9807 & 0.7720 & 0.9312 & 0.3470 & 0.9824 & 0.7810 & 0.9684 & 0.6530 \\
\hline si_nilai & 1.1095 & 0.1980 & 1.1002 & 0.2760 & 1.1343 & 0.1990 & 1.0942 & 0.2820 & 1.1134 & 0.2470 \\
\hline Kj_JobInt & 1.2418 & 0.0010 & 1.2391 & 0.0020 & 1.3188 & 0.0000 & 1.2257 & 0.0020 & 1.2675 & 0.0010 \\
\hline
\end{tabular}


Table A.1. (Continued)

\begin{tabular}{|c|c|c|c|c|c|c|c|c|c|c|}
\hline \multirow[b]{2}{*}{ Variable } & \multicolumn{2}{|c|}{ Cox } & \multicolumn{2}{|c|}{ Exponential } & \multicolumn{2}{|c|}{$\begin{array}{l}\text { Piecewise-Constant } \\
\text { Exponential }\end{array}$} & \multicolumn{2}{|c|}{ Weibull } & \multicolumn{2}{|c|}{ Gompertz } \\
\hline & $\begin{array}{c}\text { Hazard } \\
\text { Ratio }\end{array}$ & $P$-Value & $\begin{array}{c}\text { Hazard } \\
\text { Ratio }\end{array}$ & $P$-Value & $\begin{array}{c}\text { Hazard } \\
\text { Ratio }\end{array}$ & $P$-Value & $\begin{array}{c}\text { Hazard } \\
\text { Ratio }\end{array}$ & $P$-Value & $\begin{array}{c}\text { Hazard } \\
\text { Ratio }\end{array}$ & $P$-Value \\
\hline TK_Pterkini & 0.9328 & 0.3340 & 0.9614 & 0.6050 & 0.9163 & 0.3060 & 0.9620 & 0.5940 & 0.9504 & 0.5280 \\
\hline TK_online & 1.0769 & 0.3260 & 1.0385 & 0.6420 & 1.0717 & 0.4330 & 1.0358 & 0.6500 & 1.0538 & 0.5400 \\
\hline TK_qual & 0.9957 & 0.9510 & 1.0236 & 0.7540 & 1.0037 & 0.9640 & 1.0279 & 0.7010 & 1.0120 & 0.8790 \\
\hline Km_lib & 0.8237 & 0.0030 & 0.8074 & 0.0030 & 0.8083 & 0.0080 & 0.8170 & 0.0030 & 0.7998 & 0.0040 \\
\hline Km_makmal & 1.0699 & 0.3070 & 1.0463 & 0.5240 & 1.0773 & 0.3410 & 1.0495 & 0.4760 & 1.0537 & 0.4870 \\
\hline Km_sukan & 1.1219 & 0.0660 & 1.1183 & 0.0900 & 1.1421 & 0.0760 & 1.1128 & 0.0880 & 1.1282 & 0.0850 \\
\hline Km_hostel & 0.9008 & 0.0770 & 0.9162 & 0.1700 & 0.8773 & 0.0680 & 0.9134 & 0.1350 & 0.9097 & 0.1610 \\
\hline Km_carpark & 1.0014 & 0.9750 & 0.9993 & 0.9880 & 1.0212 & 0.6860 & 0.9992 & 0.9860 & 1.0024 & 0.9620 \\
\hline Ki_BM & 0.8691 & 0.0290 & 0.8377 & 0.0070 & 0.8352 & 0.0170 & 0.8518 & 0.0110 & 0.8286 & 0.0070 \\
\hline Ki_BI & 0.7774 & 0.0010 & 0.7756 & 0.0010 & 0.7352 & 0.0000 & 0.7868 & 0.0010 & 0.7564 & 0.0010 \\
\hline kb_isuSemasa & 1.0963 & 0.2180 & 1.0796 & 0.3420 & 1.1074 & 0.2410 & 1.0797 & 0.3190 & 1.0861 & 0.3290 \\
\hline Kb_dKerja & 0.9166 & 0.2560 & 0.9360 & 0.4300 & 0.9221 & 0.3740 & 0.9329 & 0.3850 & 0.9348 & 0.4440 \\
\hline
\end{tabular}

Note: Please refer to Appendix $\mathrm{C}$ for the definition and measurement of these variables.

\section{Appendix B. Out-of-Sample Validation}

Table B.1. Cox Model

\begin{tabular}{lcccccc}
\hline & \multicolumn{5}{c}{ Bottom (Low Employability) } \\
\cline { 2 - 7 } Out-of-Sample & $5 \%$ & $10 \%$ & $20 \%$ & $30 \%$ & $40 \%$ & $50 \%$ \\
\hline \% Correctly predicted & 80.95 & 73.17 & 6.14 & 64.46 & 62.35 & 60.48 \\
\% Wrongly predicted & 4.76 & 4.88 & 9.88 & 14.05 & 16.05 & 17.33 \\
Sample size & 21 & 41 & 81 & 121 & 162 & 202 \\
\hline
\end{tabular}

Table B.2. Exponential Model

\begin{tabular}{lcccccc}
\hline & \multicolumn{5}{c}{ Bottom (Low Employability) } \\
\cline { 2 - 7 } Out-of-Sample & $5 \%$ & $10 \%$ & $20 \%$ & $30 \%$ & $40 \%$ & $50 \%$ \\
\hline \% Correctly predicted & 0.04 & 4.88 & 25.93 & 44.63 & 49.38 & 50.99 \\
\% Wrongly predicted & 0.29 & 60.98 & 49.38 & 33.88 & 29.63 & 29.70 \\
Sample size & 21 & 41 & 81 & 121 & 162 & 202 \\
\hline
\end{tabular}


Table B.3. Piecewise-Constant Exponential Model

\begin{tabular}{lcccccc}
\hline & \multicolumn{5}{c}{ Bottom (Low Employability) } \\
\cline { 2 - 7 } Out-of-Sample & $5 \%$ & $10 \%$ & $20 \%$ & $30 \%$ & $40 \%$ & $50 \%$ \\
\hline \% Correctly predicted & 60.42 & 58.24 & 57.06 & 49.15 & 48.76 & 50.30 \\
\% Wrongly predicted & 10.42 & 17.58 & 24.54 & 30.93 & 32.16 & 31.71 \\
Sample size & 48 & 91.00 & 163.00 & 236.00 & 283.00 & 328.00 \\
\hline
\end{tabular}

Table B.4. Weibull Model

\begin{tabular}{lcccccc}
\hline & \multicolumn{5}{c}{ Bottom (Low Employability) } \\
\cline { 2 - 7 } Out-of-Sample & $5 \%$ & $10 \%$ & $20 \%$ & $30 \%$ & $40 \%$ & $50 \%$ \\
\hline \% Correctly predicted & 9.52 & 24.39 & 35.80 & 46.28 & 51.23 & 53.47 \\
\% Wrongly predicted & 0.00 & 39.02 & 39.51 & 33.06 & 28.40 & 27.72 \\
Sample size & 21 & 41 & 81 & 121 & 162 & 202 \\
\hline
\end{tabular}

Table B.5. Gompertz Model

\begin{tabular}{lcccccc}
\hline & \multicolumn{5}{c}{ Bottom (Low Employability) } \\
\cline { 2 - 7 } Out-of-Sample & $5 \%$ & $10 \%$ & $20 \%$ & $30 \%$ & $40 \%$ & $50 \%$ \\
\hline \% Correctly predicted & 0.00 & 2.44 & 25.93 & 42.98 & 47.53 & 49.01 \\
\% Wrongly predicted & 52.38 & 63.41 & 49.38 & 36.36 & 32.10 & 32.18 \\
Sample size & 21 & 41 & 81 & 121 & 162 & 202 \\
\hline
\end{tabular}


Appendix C. Definition and Measurement of Variables

\begin{tabular}{|c|c|c|}
\hline Code & Definition & Measurement \\
\hline Emp_status & Employment status & $\begin{array}{l}0=\text { unemployed } \\
1=\text { Part-time employment } \\
2=\text { Full-time employment does not } \\
\quad \text { commensurate with } \\
\quad \text { qualification }{ }^{\mathrm{a}} \\
3=\text { Full-time employment does } \\
\quad \text { commensurate with }^{\text {qualification }}{ }^{\mathrm{b}} \\
\quad \text { Further studies } \\
4=\text { Futhers } \\
5=\text { Other }\end{array}$ \\
\hline Gender & Gender & $1=$ Male $; 0=$ female \\
\hline Age & Age & Years \\
\hline Dinc1000 & $\begin{array}{l}\text { Dummy variable for household income } \\
\text { category of RM 500-RM } 1000\end{array}$ & $\begin{array}{l}\text { Comparison group: less than } \\
\text { RM500 }\end{array}$ \\
\hline Dinc1500 & $\begin{array}{l}\text { Household income category between } \\
\text { RM 1001-RM } 1500\end{array}$ & \\
\hline Dinc2000 & $\begin{array}{l}\text { Household income category between } \\
\text { RM 1501-RM } 2000\end{array}$ & \\
\hline Dinc2500 & $\begin{array}{l}\text { Household income category between } \\
\text { RM 2001-RM } 2500\end{array}$ & \\
\hline Dinc3000 & $\begin{array}{l}\text { Household income category between } \\
\text { RM 2501-RM } 3000\end{array}$ & \\
\hline Dinc5000 & $\begin{array}{l}\text { Household income category between } \\
\text { RM 3001-RM } 5000\end{array}$ & \\
\hline Dinc5001 & $\begin{array}{l}\text { Household income category of more } \\
\text { than RM } 5001\end{array}$ & \\
\hline CGPA & CGPA & \\
\hline English & Proficiency of English language & $\begin{array}{l}\text { Rating scale of } 1 \text { (very unsatisfac- } \\
\text { tory) to } 5 \text { (very satisfactory) }\end{array}$ \\
\hline $\operatorname{cs} 10$ & Communication skills & $\begin{array}{l}\text { Rating scale from } 0 \text { (do not reflect } \\
\text { me at all) to } 10 \text { (reflects me very } \\
\text { well) }\end{array}$ \\
\hline $\operatorname{cs} 102$ & Squared of cs10 & \\
\hline $\operatorname{ctps} 10$ & Critical and problem solving skills & $\begin{array}{l}\text { Rating scale from } 0 \text { (do not reflect } \\
\text { me at all) to } 10 \text { (reflects me very } \\
\text { well) }\end{array}$ \\
\hline ctps 102 & Squared of ctps 102 & \\
\hline ts 10 & Team work skills & $\begin{array}{l}\text { Rating scale from } 0 \text { (do not reflect } \\
\text { me at all) to } 10 \text { (reflects me very } \\
\text { well) }\end{array}$ \\
\hline
\end{tabular}

(Continued) 


\section{(Continued)}

\begin{tabular}{|c|c|c|}
\hline Code & Definition & Measurement \\
\hline ts 102 & Squared of ts 10 & \\
\hline em10 & Professional ethics and moral & $\begin{array}{l}\text { Rating scale from } 0 \text { (do not reflect } \\
\text { me at all) to } 10 \text { (reflects me very } \\
\text { well) }\end{array}$ \\
\hline em102 & Squared of em10 & \\
\hline ls 10 & Leadership skills & $\begin{array}{l}\text { Rating scale from } 0 \text { (being do not } \\
\text { reflect me at all) to } 10 \text { (reflects } \\
\text { me very well) }\end{array}$ \\
\hline ls102 & Squared of ls 10 & \\
\hline 1110 & $\begin{array}{l}\text { Information management and life-long } \\
\text { learning }\end{array}$ & $\begin{array}{l}\text { Rating scale from } 0 \text { (do not reflect } \\
\text { me at all) to } 10 \text { (reflects me very } \\
\text { well) }\end{array}$ \\
\hline 11102 & Squared of 1110 & \\
\hline kk10 & Entrepreneurship skills & $\begin{array}{l}\text { Rating scale from } 0 \text { (do not reflect } \\
\text { me at all) to } 10 \text { (reflects me very } \\
\text { well) }\end{array}$ \\
\hline kk102 & Squared of kk102 & \\
\hline ki10 & English communication skills & $\begin{array}{l}\text { Rating scale from } 0 \text { (do not reflect } \\
\text { me at all) to } 10 \text { (reflects me very } \\
\text { well) }\end{array}$ \\
\hline ki102 & Squared of ki10 & \\
\hline \multicolumn{3}{|c|}{ Self-rated satisfaction on university learning process } \\
\hline Ku_dkerja & $\begin{array}{l}\text { Curriculum in preparing student for } \\
\text { working life }\end{array}$ & $\begin{array}{l}\text { Rating scale from } 1 \text { (not satisfying } \\
\text { at all) to } 5 \text { (very satisfying) }\end{array}$ \\
\hline si_nilai & Evaluation system & $\begin{array}{l}\text { Rating scale from } 1 \text { (not satisfying } \\
\text { at all) to } 5 \text { (very satisfying) }\end{array}$ \\
\hline $\mathrm{Kj} \_$JobInt & $\begin{array}{l}\text { Career — help to improve job inter- } \\
\text { view skills }\end{array}$ & $\begin{array}{l}\text { Rating scale from } 1 \text { (not satisfying } \\
\text { at all) to } 5 \text { (very satisfying) }\end{array}$ \\
\hline TK_Pterkini & $\begin{array}{l}\text { Staff - explore student to current } \\
\text { knowledge in the field of study }\end{array}$ & $\begin{array}{l}\text { Rating scale from } 1 \text { (not satisfying } \\
\text { at all) to } 5 \text { (very satisfying) }\end{array}$ \\
\hline TK_online & Staff — provide online interaction & $\begin{array}{l}\text { Rating scale from } 1 \text { (not satisfying } \\
\text { at all) to } 5 \text { (very satisfying) }\end{array}$ \\
\hline TK_qual & Staff — qualification & $\begin{array}{l}\text { Rating scale from } 1 \text { (not satisfying } \\
\text { at all) to } 5 \text { (very satisfying) }\end{array}$ \\
\hline Km_lib & Facilities - library & $\begin{array}{l}\text { Rating scale from } 1 \text { (not satisfying } \\
\text { at all) to } 5 \text { (very satisfying) }\end{array}$ \\
\hline Km_makmal & $\begin{array}{l}\text { Facilities — laboratory, studio, work- } \\
\text { shop etc }\end{array}$ & $\begin{array}{l}\text { Rating scale from } 1 \text { (not satisfying } \\
\text { at all) to } 5 \text { (very satisfying) }\end{array}$ \\
\hline Km_sukan & Facilities - sport and recreation & $\begin{array}{l}\text { Rating scale from } 1 \text { (not satisfying } \\
\text { at all) to } 5 \text { (very satisfying) }\end{array}$ \\
\hline Km_hostel & Facilities - accommodation & $\begin{array}{l}\text { Rating scale from } 1 \text { (not satisfying } \\
\text { at all) to } 5 \text { (very satisfying) }\end{array}$ \\
\hline Km_carpark & Facilities - car park & $\begin{array}{l}\text { Rating scale from } 1 \text { (not satisfying } \\
\text { at all) to } 5 \text { (very satisfying) }\end{array}$ \\
\hline
\end{tabular}


(Continued)

\begin{tabular}{|c|c|c|}
\hline Code & Definition & Measurement \\
\hline i_BM & Malay language proficiency & $\begin{array}{l}\text { Rating scale from } 1 \text { (not satisfying } \\
\text { at all) to } 5 \text { (very satisfying) }\end{array}$ \\
\hline Ki_BI & English language proficiency & $\begin{array}{l}\text { Rating scale from } 1 \text { (not satisfying } \\
\text { at all) to } 5 \text { (very satisfying) }\end{array}$ \\
\hline kb_isuSemasa & $\begin{array}{l}\text { Effectiveness - development of cur- } \\
\text { rent issues }\end{array}$ & $\begin{array}{l}\text { Rating scale from } 1 \text { (no influence at } \\
\text { all) to } 5 \text { (very high influence) }\end{array}$ \\
\hline Kb_dKerja & $\begin{array}{l}\text { Effectiveness - prepare for outside } \\
\text { world and job }\end{array}$ & $\begin{array}{l}\text { Rating scale from } 1 \text { (no influence at } \\
\text { all) to } 5 \text { (very high influence) }\end{array}$ \\
\hline ersepsi & $\begin{array}{l}\text { Overall perception on the learning } \\
\text { process }\end{array}$ & $\begin{array}{l}\text { Rating scale from } \\
\text { all) to } 5 \text { (very }\end{array}$ \\
\hline egree $1-12$ & Dummy variable for types of degree ${ }^{c}$ & \\
\hline Jniversity $1-17$ & Dummy variable for & \\
\hline \multicolumn{3}{|c|}{$\begin{array}{l}\text { Notes } \\
\text { aFull-time employment that does not commensurate with qualification refers to full-time employed graduates } \\
\text { who work in the job categories of "clerical support workers", "service and sales workers", skilled agri- } \\
\text { cultural, forestry and fishery workers, craft and related trade workers", and "plant and machine operators } \\
\text { and assemblers" (Malaysia Standard of Classification of Occupations 2008). } \\
\text { bFull-time employment that does commensurate with qualification refers to full-time employed graduates } \\
\text { who work in the job categories of "managers", "professionals" and "technicians and associate profes- } \\
\text { sionals". } \\
\text { cSome variables (Degree 1-12, and University 1-17 have to be classified as 'anonymous' for reasons of data } \\
\text { confidentiality and sensitivity. }\end{array}$} \\
\hline
\end{tabular}

\section{Appendix D. D.1}

$$
\begin{aligned}
& \text { Predicted hazard: } \hat{h}_{i}(t) \\
&= h_{0}(t) \exp \left[x_{i} \beta\right] \\
&= h_{0}(t) \exp [0.4735 g e+0.2838 \text { Dinc } 1000+0.4294 \text { Dinc } 1500+0.2198 \text { Dinc2000 } \\
&+0.3389 \text { Dinc2500 }+0.0462 \text { Dinc3000 }+0.2805 \text { Dinc5000 }+0.2624 \text { Dinc5001 } \\
&-0.5271 \text { degree } 1-2.2592 \text { degree } 2-1405 \text { degree } 3-2.2254 \text { degree } 4 \\
&-0.8013 \text { degree } 5-0.0071 \text { degree } 6+0.2089 \text { degree } 7-0.0052 \text { degree } 8 \\
&-0.039 \text { degree } 9-0.0993 \text { degree } 10-0.2406 \text { degree } 11-0.1318 \text { degree } 12 \\
&-0.2693 \text { university } 1-0.1342 \text { university } 2-0.3139 \text { university3 } \\
&-0.4864 \text { university } 4-0.209 \text { university } 5-0.5908 \text { university } 6-1.3767 \text { university } 7 \\
&-1.1335 \text { university } 8-0.5897 \text { university } 9+0.2244 \text { university } 10 \\
&-0.1198 \text { university } 11-2.1326 \text { university } 12-1.9977 \text { university } 13 \\
&-2.8885 \text { university } 14-0.737 \text { university } 15-0.7629 \text { university } 16 \\
&-1.1143 \text { university } 17+0.4263 \text { cgpa }+0.1416 \text { eng }-0.7844 \text { em } 10 \\
&+0.0544 \text { em } 102+0.2166 c 3-0.194 c 7-0.1403 c 12-0.2518 c 13] .
\end{aligned}
$$




\section{References}

Allison, DP (1984). Event History Analysis: Regression for Longitudinal Event Data. California: Sage.

Black, AD, AJ Smith, M Plesca and S Shannon (2003). Profiling UI Claimants to Allocate Reemployment Services: Evidence and Recommendations for States. ETA Occasional Papers. USA: U.S. Department of Labor.

Cargile, AC (2000). Evaluations of employment suitability: Does accent always matter? Journal of Employment Counseling, 37(3), 165-177.

Chew, CS (2013). Helping unemployed graduates in Malaysia. New Strait Times, 14 March 2013. Access on Oct. 8, 2013, from: http://www.nst.com.my/opinion/columnist/helping-unemployedgraduates-in-malaysia-1.234315.

Clark, EA and JA Oswald (1994). Unhappiness and unemployment. Economic Journal, 104(424), 648-659.

Cobb-Clark, DA and MD Connolly (2001). A family affair: The labor market experience of immigrant spouses. Social Science Quarterly, 82(4), 796-811.

Docampo, D (2007). International Comparison in Higher Education Funding. Online paper. Access on Sept. 06, 2012, from: http://www.gts.tsc.uvigo.es/ ddocampo/ONLINE/internationalfunding.pdf.

Dockery, AM (2003). Happiness, Life Satisfaction and the Role of Work: Evidence from Two Australian Surveys. Working Paper 03.10, Curtin Business School, Curtin University of Technology.

Higher Education Finance and Cost-Sharing in Malaysia (2009). Online paper. Access on Sep. 06, 2012 from: http://gse.buffalo.edu/org/inthigheredfinance/files/Country_Profiles/Asia/Malaysia. pdf.

Sarudin I, AM Zubairi, MS Nordin and TBT Ahmad (2011). English language competency for employment purposes: Meeting the needs of industry. In In the Muslim World Language Studies, Nuraihan MD, S Isarji, JM Ainon, EI Engku Haliza and O Khairiah (eds.), pp. 179-208.

Lan, P-C (2003). They have more money but I speak better English! transnational encounters between Filipina domestics and Taiwanese employers. Identities: Global Studies in Culture and Power, 10(2), 133-161.

Lazaro, N, ML Molto and R Sanchez (2000). Unemployment determinants for women in Spain. Labour, 14(1), 53-78.

Lim, HE (2008). Feasibility of early identification of low employability graduates in Malaysia. Malaysian Journal of Economic Studies, 45(2), 95-112.

Lim, HE (2010). Predicting Low Employability Graduates: The Case of Universiti Utara Malaysia. Singapore Economic Review, 55(3), 523-535.

Morshidi, S, B Rosni, HE Lim and NK Mohamed (2004a). Pencapaian akademik \& kebolehgunaan tenaga siswazah institusi Pengajian tinggi. USM IPPTN Monograf 3/2004. Penang, pp. 1-28.

Morshidi, S, AA Buang, AMM Isa, A Pandian, MA Abdullah, MD Ibrahim, MH Piei, MNN Lee, M Shuib, R Bakar, R Mustafa, SA Rahman, SZA Hamid, SSC Mey and WAK Mahmood. (2004b). Masalah pengangguran di kalangan siswazah. USM IPPTN Monograf 2/2004. Penang.

Morshidi, S, A Pandian, B Muniandy, FMM Sultan, HA Haroon, H Azman, MK Kabilan and RRA Razak (2008). The university curriculum and the employment of graduates. In Enhancing the Quality of Higher Education Through Research: Shaping Future Policy, Md. Y Abu Bakar, HM Nor Aieni, J Rohana, MZ Ainol, O Norasmah and A Gan (eds.), pp. 136-159. Malaysia: Ministry of Higher Education.

Nativel, C (2004). Economics Transition, Unemployment and Active Labour Market Policy: Lessons and Perspectives from the East German Bundeslander. UK: University of Birmingham Press. 
O'Connell, P, S McGuinness and E Kelly (2010). A statistical profiling of long-term unemployment risk in Ireland. ESRI Working paper No. 345, ESRI: Dublin.

Payne, C and J Payne (2000). Early Identification of the Long-Term Unemployed. PSI Research Discussion Paper 4. London: PSI.

Pietro, GD and A Cutillo (2006). University quality and labour market outcomes in Italy. Labour, 20(1), 37-62.

Smith, J, A McKnight and R Naylor (2000). Graduate employability: Policy and performance in higher education in the UK. Economic Journal, 110(464), 382-411.

Winkelmann, L and R Winkelmann (1998). Why are the unemployed so unhappy? Evidence from panel data. Economica, 65(257), 1-15.

Wong, Annie Muk-Ngiik and J Hamali (2006). Higher education and employment in Malaysia. International Journal of Business and Society, 7(1), 102-120.

World Bank (2007). Malaysia and the Knowledge Economy: Building a World Class Higher Education. World Bank Report No. 40397-MY, Human Development Section Report, East Asian and Pacific Region, World Bank. 